\title{
Effectiviteit van re-integratie: onbenutte potenties van privatisering
}

\author{
Wim Zwinkels*
}

Leidt privaat opdrachtnemerschap en/of opdrachtgeverschap voor re-integratie tot een grotere effectiviteit? In deze bijdrage wordt getracht een empirisch antwoord te vinden door de netto-effectiviteit van private re-integratiebedrijven zo goed mogelijk te vergelijken met die van de publieke arbeidsvoorziening. Het effect van privatisering aan de opdrachtgeverszijde wordt onderzocht door de WAO-instroom na eigenrisicodragen te analyseren. De uitkomsten lijken erop te duiden dat de diverse privatiseringsacties geen aardverschuivingen in de netto-effectiviteit teweeggebracht hebben. Privatisering aan de opdrachtgeverskant lijkt daarbij iets grotere effecten gehad te hebben dan privatisering aan de opdrachtnemerskant van re-integratie. Een belangrijk aspect daarbij is dat de effectiviteit niet voor alle klantgroepen hetzelfde is. Goede prikkels voor opdrachtgevers leiden ertoe dat deze informatie wordt onderzocht en benut bij de inzet van re-integratie. De match tussen opdrachtgever en opdrachtnemer kan verbeterd worden door gegevens over de netto-effectiviteit van aanbieders transparant en toegankelijk te maken. De invoering van privatisering alleen is niet voldoende, het gaat om het effectief benutten van de kansen die de privatisering biedt. Daartoe zijn in Nederland nog tal van onbenutte potenties.

Trefwoorden: re-integratie, privatisering, netto-effectiviteit, sociale zekerheid

\section{Inleiding}

Met de invoering van de Wet structuur uitvoeringsorganisatie werk en inkomen (SUWI) in 2002 is een concurrerende re-integratiemarkt ontstaan met meerdere aanbieders van re-integratiediensten. Deze privatisering is een geleidelijk proces geweest. Met de opkomst van private re-integratie werd de gedwongen winkelnering bij Arbeidsvoorziening stopgezet. Arbeidsvoorziening werd opgeknipt in een aantal onderdelen, waarbij de re-integratiedienstverlening op de private markt werd ondergebracht in Kliq, dat overigens inmiddels overgenomen is. Privatisering van de re-integratie van bijstandsgerechtigden is met de introductie van de Wet werk en bijstand (WWB) goed op gang gekomen.
Privatisering kan theoretisch een gunstige uitwerking op de effectiviteit hebben, aangezien private organisaties in het algemeen een grotere prikkel hebben dan publieke. De vraag is of privatiseringsacties invloed gehad hebben op de effectiviteit van re-integratie. In deze bijdrage wordt eerst stilgestaan bij het begrip effectiviteit en de methodologie rond het meten van effectiviteit. Daarna komt de invloed van privatisering op de effectiviteit van re-integratie aan de orde.

\section{Effectiviteit van re-integratie}

Effectiviteit zegt iets over het realiseren van de doelstellingen van beleid. In hoeverre zijn de effecten toe te schrijven aan het gevoerde beleid en de daarbij ingezette instrumenten? (zie Ministerie van Financiën, 2006). Voor

* Wim Zwinkels is werkzaam bij TNO Kwaliteit van Leven I Arbeid. E-mail: wim.zwinkels@tno.nl. 
arbeidsmarkt- en re-integratiebeleid is het belangrijkste doel mensen zonder arbeid te laten deelnemen aan de maatschappij middels betaalde arbeid. Veelal gaat het daarbij om mensen in een uitkeringssituatie waarvoor het doel dus is uitstroom naar betaalde arbeid te realiseren via re-integratietrajecten.

Behalve uitkeringsduurverkorting kunnen er nog andere doelen zijn van re-integratie. Effecten van re-integratie naast uitkeringsduurverkorting zijn tussendoelen op de weg naar werk als beheersing van de Nederlandse taal of een stapje hoger komen op de re-integratieladder. Daarnaast kan deelname aan reintegratie ook bevorderend zijn voor de participatie van het individu. Positieve effecten komen tot uitdrukking in het vermijden van maatschappelijk ongewenst gedrag (men hangt niet meer rond op straat) of het terugdringen van de zorgconsumptie van het individu (Brouwer, Zwinkels \& Van Genabeek, 2006; Kok, Hollanders \& Hop, 2006). Deze effecten worden belangrijker aan de onderkant van de arbeidsmarkt, bijvoorbeeld bij kansarme bijstandsgerechtigden (de 'harde kern').

Laten we vooralsnog even abstraheren van deze effecten van re-integratie en uitstroom naar betaald werk voorop stellen. Een maatstaf voor effectiviteit van re-integratietrajecten zou kunnen zijn het aantal trajecten dat geleid heeft tot uitstroom naar betaalde arbeid. We noemen dit de bruto-effectiviteit. Echter, werkzoekenden kunnen ook zelf betaalde arbeid verwerven. Het is dus niet zeker dat er bij waargenomen uitstroom naar werk een causaal verband bestaat met het reintegratietraject. Om vast te stellen wat de bijdrage geweest is van re-integratie (nettoeffectiviteit), dienen we te corrigeren voor het deadweight-losseffect. Re-integratietrajecten worden gegeven aan personen die op eigen kracht ook een baan vinden. Sterker nog, het zou het geval kunnen zijn dat personen hun eigen zoekactiviteiten naar betaalde arbeid verminderen of helemaal staken omdat ze in een re-integratietraject zitten, het zogenaamde lock-ineffect. Het moge duidelijk zijn dat, conform de definitie van het ministerie van Financiën (2006), de netto-effectiviteit van re-integratie de leidraad voor onderzoek dient te zijn.
Hoe corrigeren we nu voor deadweight-losseffecten? Allereerst kan dit via een experimentele opzet. We geven de ene groep werkzoekenden een re-integratietraject, de andere niet en het verschil in uitstroom naar betaalde arbeid is een maatstaf voor effectiviteit. Als er sprake is van gerandomiseerde toewijzing van re-integratie (zgn. randomized control trial) is het verschil in uitstroom rechtstreeks toe te wijzen aan de interventie.

$\mathrm{Nu}$ wordt er in Nederland nogal weinig geëxperimenteerd in de sociale zekerheid. En als dit al gebeurt, vindt het op zeer geringe schaal plaats, waardoor slechts zeer partiële uitspraken mogelijk zijn. In de praktijk wordt reintegratie zelden aselect gegeven. Een directe vergelijking tussen de groep met en zonder reintegratie gaat dan niet op. De kenmerken van de populatie met en zonder re-integratie kunnen verschillen, waardoor ook de kansen op de arbeidsmarkt zonder re-integratie uiteen kunnen lopen. In een quasi-experimentele onderzoeksopzet wordt zo veel mogelijk gecorrigeerd voor deze selectie-effecten. Daarbij kunnen ook econometrische methoden worden toegepast om te corrigeren voor selectie op basis van kenmerken die niet waargenomen worden (zoals motivatie), de zogenaamde niet-waargenomen heterogeniteit.

Onderzoek naar de gevolgen van privatisering van de uitvoering, een megaoperatie op beleids- en uitvoeringsniveau, zijn methodologisch nog lastiger. Situaties waarin re-integratie publiek en privaat uitgevoerd worden, liggen grotendeels in een ander tijdvak. De vergelijking wordt dus extra bemoeilijkt door verschillen in de conjuncturele situatie, die na de privatisering aanmerkelijk slechter was dan ervoor (zie ook Wevers et al., 2006). Daarnaast gebeurde er tegelijkertijd veel aan de uitvoeringskant. De aard van SUWI was immers een organisatiewet: door nauwere samenwerking tussen organisaties als Centrum voor Werk en Inkomen (CWI) en Uitvoeringsinstituut Werknemersverzekeringen (UWV) dienden twee hoofddoelstellingen van SUWI gerealiseerd te worden. 'Werk boven uitkering', dat uiteenvalt in het beperken van de instroom (preventie), het bevorderen van de re-integratie en het bevorderen van een tij- 
dige en juiste uitkeringsverstrekking. En 'De klant centraal' waarbij het gaat om het vergroten van de klantgerichtheid en het bevorderen van de cliëntenparticipatie. Ook de materiewetgeving veranderde in dezelfde periode sterk. Tegelijkertijd met SUWI en de privatisering van de re-integratie werd de Wet verbetering poortwachter ingevoerd, kwam er een nieuw Schattingsbesluit voor arbeidsongeschiktheid en werden WW-eisen aangescherpt. Los van de regelgeving werd ook de uitvoering flink aangescherpt, bijvoorbeeld tot uitdrukking komend in het handhavingsbeleid bij de gemeentelijke bijstand. Het effect van privatisering is daarmee zeer lastig te isoleren van andere maatregelen en tegelijkertijd optredende effecten.

\section{Gevolgen privatisering opdrachtnemer- schap}

Er is het nodige empirische onderzoek gedaan naar de netto-effectiviteit van de geprivatiseerde re-integratiedienstverlening in Nederland, waarbij rekening gehouden wordt met selectie-effecten op basis van waargenomen en soms ook niet-waargenomen kenmerken. Heyma (2005), Zwinkels (2005), Heyma, Zwinkels en Van Seters (2003), Van der Heul et al. (2003) en De Graaf-Zijl, Groot en Hop (2006a) gaan in op de effecten van re-integratie voor arbeidsgehandicapten en/of werklozen. In het algemeen worden in genoemde studies significante uitkeringsduurverkortende effecten van re-integratietrajecten gevonden. Het blijkt dat de effecten van reintegratie gunstiger zijn naarmate de afstand tot de arbeidsmarkt groter wordt. Van der Heul (2006) vindt bijvoorbeeld geringe effecten van re-integratiemaatregelen voor WWcliënten, met uitzondering van laag opgeleiden, vrouwen en allochtonen. Vooral de effecten van scholing zijn gering of negatief. Voor kansrijke cliënten werkt scholing vaak contraproductief en duurverlengend. Tijdens de scholingsperiode wordt er niet actief naar werk gezocht. Ook in internationale studies worden deze resultaten veelal gevonden (zie De Koning et al., 2005).

Ook in de eerste onderzoeken naar effectiviteit van re-integratietrajecten voor bij- standsgerechtigden, die thans beschikbaar komen, worden veelal duurverkortende effecten van re-integratie gevonden. Er zijn nettoeffectiviteitsonderzoeken voor de gemeenten Rotterdam (Hekelaar, Zwinkels \& Braat, 2006) en Amsterdam (De Graaf-Zijl, Heyma \& De Hoop, 2006b) en landelijke analyses (Kok et al., 2006; De Graaf-Zijl et al., 2006a). Overigens verschilt de mate van effectiviteit tussen diverse instrumenten of trajecten.

Hoewel het gros der onderzoeken laat zien dat re-integratiedienstverlening, uitgevoerd door private bedrijven, (zij het soms gering) nettoeffectief is en dus de kans op uitstroom uit de uitkering naar werk vergroot in vergelijking met een situatie waarin geen re-integratietraject plaatsvindt, zegt dit nog niets over de effectiviteit van private re-integratiedienstverlening ten opzichte van de eerdere publieke uitvoering. Misschien was deze wel net zo effectief of zelfs effectiever. Methodologisch deugdelijke onderzoeken naar re-integratie voor de tijd dat Arbeidsvoorziening monopolist was, zijn schaars en lastig vergelijkbaar, met uitzondering van Heyma (2002). Hij vindt dat het beleid van Arbeidsvoorziening voor de re-integratie van arbeidsgehandicapten netto-effectief is geweest.

De introductie van marktwerking is, zoals eerder opgemerkt, een tamelijk geleidelijk proces geweest. Dit betekent dus dat er tijdelijk een zekere hybride situatie is geweest met een mix van re-integratieactiviteiten van Arbeidsvoorziening en de eerste door het UWV aanbestede re-integratiecontracten uitgevoerd door private partijen. In Zwinkels (2005) wordt gebruikgemaakt van dit feit en worden prestaties van individuele re-integratiebedrijven voor WW-gerechtigden onderzocht. In het onderzoek is een multivariate duuranalyse uitgevoerd waarbij gecorrigeerd is voor niet-waargenomen heterogeniteit in de duur.

Tabel 1 geeft de netto-effectiviteit weer van de re-integratiebedrijven. In dit geanonimiseerde overzicht staan trajecten van Arbeidsvoorziening en de opvolger Kliq tussen andere bedrijven als Alexander Calder, Agens en Fourstar. 
Tabel 1 Hazard ratio's* van private re-integratiebedrijven en Arbeidsvoorziening

\begin{tabular}{llc}
\hline $\begin{array}{l}\text { Re-integratie- } \\
\text { bedrijf }\end{array}$ & $\begin{array}{l}\text { Hazard } \\
\text { ratio }\end{array}$ & $\begin{array}{l}\text { Aantal } \\
\text { trajecten }\end{array}$ \\
\hline $1 \quad$ Rib 1 & 6,76 & 117 \\
$2 \quad$ Rib 2 & 5,70 & 35 \\
$3 \quad$ Rib 3 & 5,27 & 273 \\
$\ldots \ldots$ & $\ldots$ & 4.697 \\
11 Arbeids- & 3,12 & \\
$\quad$ voorziening & $\ldots$ & 1.270 \\
$\ldots \ldots$ Kliq & 1,34 & 99 \\
$\ldots . \ldots$ & $\ldots$ & \\
24 Rib 24 & 0,32 & 23.245 \\
gewogen & 2,09 & \\
gemiddelde & &
\end{tabular}

* Een hazard ratio geeft de relatieve kans op uitstroom met re-integratietraject ten opzichte van geen re-integratietraject. Bij een hazard ratio van één zijn beide kansen aan elkaar gelijk, bij een kans tussen nul en één is de kans op uitstroom zonder re-integratietraject groter dan met een traject.

De uitkomsten laten zien dat de re-integratieresultaten van Arbeidsvoorziening (bijna 4.700 trajecten in de dataset) zo slecht nog niet waren. Het bedrijf neemt een middenpositie in en scoort toch beduidend beter dan het gewogen gemiddelde van de markt (inclusief Arbeidsvoorziening zelf). Opvallend is dat de prestaties van opvolger Kliq beduidend minder zijn. Mogelijk heeft dit te maken met een uittocht van de beste medewerkers van Kliq. Immers, de private re-integratiebedrijven die kavels gewonnen hadden in de eerste aanbesteding van de uitvoeringsinstellingen sociale verzekeringen (uvi's; de vorming van het UWV moest toen nog plaatsvinden), moesten flink uitbreiden om de trajecten te kunnen uitvoeren.

Interessant is ook om te kijken wat er in andere landen gebeurd is met de effectiviteit na privatisering. $\mathrm{Nu}$ zijn er weinig landen waar de privatisering van re-integratie zo grondig ter hand is genomen als in Nederland. De meest vergelijkbare situatie is Australië. Opvallend genoeg zijn de twee grootste marktpartijen aldaar niet bepaald typische private ondernemingen: de Salvation Army (het Leger des Heils) en de christelijke organi- satie Mission Australia. Het is daar dus anders verlopen dan in Nederland, waar Kliq inmiddels na faillissement overgenomen is door Agens.

Uiteraard kent de bovenstaande empirische analyse ook de nodige mitsen en maren. Het kan zijn dat de correctie in de analyse voor conjunctuur- en beleidseffecten niet afdoende is, zodat de effectiviteit verkeerd ingeschat wordt. Meer fundamenteel is de vraag wat de beleidsmatige relevantie van de resultaten is. Mogelijk wordt de effectiviteit van private reintegratiebedrijven onderschat. Er was immers sprake van een opstartende markt, zodat private re-integratiebedrijven de meest effectieve werkwijze nog moesten uitvinden. Bovendien kan gesteld worden dat de marktwerking nog goed op gang moest komen. Marktwerking leidt niet automatisch tot een betere prijs-prestatieverhouding van het product re-integratie. Daarvoor zijn de volgende, onderling samenhangende, voorwaarden noodzakelijk, waar achtereenvolgens op wordt ingegaan.

- De effectiviteitscores van aanbieders op de markt dienen transparant te zijn, zodat opdrachtgevers de meest geschikte aanbieder kunnen contracteren.

- Effectieve re-integratie is na de privatisering niet alleen een zaak van de opdrachtnemer: de opdrachtgever dient ervoor te zorgen dat de juiste klant op het juiste traject terechtkomt.

- Er dienen voldoende prikkels te zijn voor de opdrachtgever. De vraag daarbij is of publieke opdrachtgevers voldoende prikkels hebben of dat privaat opdrachtgeverschap leidt tot een grotere effectiviteit van re-integratie.

\section{Transparantie van effectiviteitscores}

Effectiviteit van re-integratie is op twee manieren afhankelijk van de transparantie van effectiviteitscores van re-integratiebedrijven. Ten eerste leidt transparantie tot meer concurrentie. Het wordt voor individuele reintegratiebedrijven in geval van transparantie lonend om zich te richten op netto-effectiviteit, aangezien de resultaten beloond worden. Ten tweede zorgt transparantie ervoor 
dat opdrachtgevers de juiste opdrachtnemers kunnen selecteren. De effectiviteit van de markt als geheel kan dan toenemen. Kortom, de door de wetgever beoogde prikkel van marktwerking werkt pas op het moment dat de resultaten van deze prikkels transparant zijn. ${ }^{1}$

Het monitoren van de netto-effectiviteit van aanbieders is op dit moment in Nederland sterk voor verbetering vatbaar (Zwinkels, Van Genabeek \& Groot, 2004). Het keurmerk voor re-integratie van de brancheorganisatie voor re-integratiebedrijven Borea, opgegaan in de Stichting Blik op Werk, bevat alleen gegevens over de bruto-effectiviteit, naast gegevens over onder meer klanttevredenheid en doorlooptijden. Ook de overzichten van het UWV met plaatsingscijfers van re-integratiebedrijven bieden slechts inzicht in de bruto-effectiviteit. Er is geen rekening gehouden met de kenmerken van de populatie die een re-integratietraject krijgt en de snelheid waarmee cliënten geplaatst worden na aanlevering door het UWV. Voor de gemeentelijke re-integratiemarkt is de informatielacune nog groter en is de informatie meer versnipperd.

Het is interessant om ook hier te kijken naar het buitenland, wederom naar Australië. Dat land heeft een benchmarksysteem voor nettoeffectiviteit met star ratings. Re-integratiebedrijven kunnen maximaal vijf sterren scoren met intervallen van halve sterren. Dit systeem is gericht op het meten van de effectiviteit van re-integratiebedrijven, waarbij rekening wordt gehouden met de omgeving waar de aanbieders opereren (de lokale arbeidsmarkt) en de kenmerken van de cliënten op grond van de JSCI-score (Jobseeker Classification Instrument). Het publieke Centrelink, het Australische CWI, kent op grond van veertien factoren met econometrisch bepaalde gewichten een score toe die de afstand tot de arbeidsmarkt weergeeft. Aan de hand van de JSCI-score wordt tevens bekeken voor welke re-integratievoorzieningen de cliënt in aanmerking komt. De star rating wordt niet alleen bepaald door het percentage succesvolle plaatsingen, maar hangt ook af van afstand tot de arbeidsmarkt, via de JSCIscore, van gere-integreerde cliënten.
$\mathrm{Na}$ invoering van het systeem met star ratings zijn de plaatsingscijfers van re-integratiebedrijven in Australië spectaculair gestegen, hoewel zich ook hier leereffecten kunnen hebben voorgedaan. De wijze waarop star ratings berekend worden, is overigens niet openbaar. Dit is het geval om te voorkomen dat re-integratiebedrijven zich gaan richten op gevallen waarmee ze hun rating snel kunnen opschroeven, of hun inspanningen verminderen wanneer ze net over de grens van een sterpunt zijn gegaan en de volgende sterpunt buiten hun bereik ligt.

\section{Effectieve aanbesteding}

Bij de beoordeling van effectiviteitscores van aanbieders is het van belang te realiseren dat deze ook beïnvloed kunnen zijn door het aanbestedingsproces met de aanbestedende partij. Effectiviteit is niet alleen een kwestie van goed opdrachtnemerschap, maar ook van goed opdrachtgeverschap.

Allereerst kunnen via de contractvoorwaarden en de wijze van aanbesteding de prikkels voor opdrachtnemers niet optimaal afgesteld staan, waardoor het voor private re-integratiebedrijven die winst willen maken niet aantrekkelijk is om tot het uiterste voor iedere cliënt te gaan bij re-integratie. Met name op de gemeentelijke re-integratiemarkt is er veel op prijs geconcurreerd in aanbestedingsprocedures. Daarnaast hebben resultaatafspraken in contracten veelal de vorm van plaatsingscijfers. Het is dan voor een re-integratiebedrijf lonender om het kansrijke deel van de populatie af te romen, terwijl de nettoeffectiviteit van re-integratie voor deze populatie veelal lager is. Op netto-effectiviteit wordt niet gestuurd. Ook in de uitvoering kan de aanlevering van cliënten procesmatig niet soepel verlopen zijn.

Daarnaast betekenen de eerdergenoemde verschillen in effectiviteit tussen cliëntgroepen dat bij aanbestedingen rekening gehouden kan worden met verschillen in de verwachte effectiviteit van de diverse re-integratietrajecten. Werken met klantprofielen, het inzetten van re-integratie aan cliëntgroepen die daar het meeste baat bij hebben, is dus een essen- 
tiële taak van de opdrachtgever. Heyma en Zwinkels (2004) constateren al dat door doelgroepen voor de aanbesteding van re-integratietrajecten anders in te delen, re-integratieinspanningen beter kunnen renderen. Ook op de gemeentelijke re-integratiemarkt zijn er duidelijke aanwijzingen dat de netto-effectiviteit door herallocatie van beschikbare reintegratiemiddelen vergroot kan worden (zie Hekelaar et al., 2006; De Graaf-Zijl et al., $2006 b)$. Het is dan onterecht om louter de opdrachtnemers te verwijten niet de grootste inspanning te leveren.

\section{Privatisering van opdrachtgeverschap}

De re-integratiemarkt wordt gekenmerkt door verschillende principal-agentrelaties. Voor werklozen en arbeidsgehandicapten huurt het UWV (principal) re-integratiebedrijven (agents) in. Het UWV is zelf ook een agent als zelfstandig bestuursorgaan van de overheid. Het ministerie van Sociale Zaken ziet er daarbij op toe dat publiek geld goed besteed wordt. Het Centraal Planbureau (CPB) (Koning \& Deelen, 2003) constateert echter dat het UWV vooral is afgerekend op het uitvoeren van de Sluitende Aanpak (iedereen binnen 12 maanden op een traject) en veel minder op de effectiviteit van trajecten. De sluitende aanpak als leidend principe is inmiddels losgelaten. Net als bij opdrachtnemers is ook aan de opdrachtgeverskant de vraag wat de gevolgen (zouden) zijn van privatisering.

$\mathrm{Nu}$ treedt in de sociale zekerheid het laatste decennium in Nederland op onderdelen ook privatisering van het opdrachtgeverschap op. In 1994 werden eigenrisicoperioden geïntroduceerd van twee (voor kleine werkgevers) en zes weken, waarna vanaf 1996 de loondoorbetaling een jaar werd. In 2004 werd de Wet verlenging doorbetalingsverplichting bij ziekte van kracht, wat de loondoorbetaling op twee jaar bracht. Bij de arbeidsongeschiktheidswetgeving zijn er mogelijkheden tot eigenrisicodragen. Daarnaast is de Werkhervattingsregeling Gedeeltelijk Arbeidsgeschikten (WGA), als onderdeel van de Wet werk en inkomen naar arbeidsvermogen (WIA) met ingang van 2006 geprivatiseerd. Vanaf SUWI wordt strikt het principe gehanteerd dat degene die de uitkering betaalt verantwoordelijk is voor de reintegratie.

De vraag naar de gevolgen van privatisering van de opdrachtgevers voor de effectiviteit is net als bij de privatisering van de opdrachtnemers lastig te beantwoorden door soortgelijke methodologische problemen. Situaties voor en na privatisering dienen met elkaar vergeleken te worden, waarbij verstorende effecten als veranderingen in de conjuncturele situatie en wijzigingen in materiewetgeving en/of uitvoering optreden. De inmiddels achterhaalde Wet Pemba (Premiedifferentiatie en marktwerking bij arbeidsongeschiktheidsverzekeringen) die per 1 januari 1998 is ingevoerd, biedt echter mogelijkheden om publiek en privaat opdrachtgeverschap met elkaar te vergelijken.

Het doel van Pemba is om werkgevers te stimuleren een effectief preventief arbo- en verzuimbeleid te voeren door adequate arbeidsomstandigheden aan te bieden. Werkgevers krijgen hiertoe een financiële prikkel in de vorm van een aangepaste WAO-premie. Pemba bood de individuele werkgever tevens de mogelijkheid om uit het publieke bestel te treden (opting out) en eigenrisicodrager te worden voor de eerste vijf jaar van arbeidsongeschiktheid van zijn werknemers in plaats van publiek verzekerd te zijn, waarbij het UWV uitvoerder was. De beslissing omtrent inzet en inhoud van re-integratie is ook privaat in geval van eigenrisicodragen conform het principe dat degene die de uitkering betaalt verantwoordelijk is voor de re-integatie. De werkgever kan zich voor het uitkeringsrisico verzekeren bij een private verzekeraar. Ook dan blijft de beslissing over re-integratie in het private domein.

Zwinkels, Brouwer en Braat (2006) hebben onderzocht wat de verschillen in WAOinstroom tussen werkgevers in het publieke en private bestel zijn. Daarbij zijn gegevens van het UWV over de WAO-instroom in de jaren 2000 tot en met 2004 gebruikt van ongeveer 350.000 werkgevers per jaar. Achtergrondkenmerken die gebruikt zijn bij de analyse hebben betrekking op de personeelsomvang, de opbouw van het personeelsbestand 
en de sector van de werkgever. De gegevens van het UWV bevatten informatie over het feit of een werkgever via het omslagstelsel is verzekerd of eigenrisicodrager is. Niet bekend is welke van de uitgetreden werkgevers het risico vervolgens verzekerd hebben bij een particuliere verzekeraar. Ook zijn er geen landelijke cijfers beschikbaar over het aantal uitgetreden werkgevers die het WAO-risico alsnog verzekerd hebben. Over het algemeen wordt wel aangenomen dat de meeste werkgevers een verzekering hebben afgesloten voor (een deel van) het risico. Dit betekent dat deze analyse een goede vergelijking oplevert tussen een publieke uitvoering en het eigenrisicodragen, al dan niet verzekerd bij private verzekeraars.

In de analyses is rekening gehouden met het feit dat de keuze om eigenrisicodrager te worden, samenhangt met het WAO-risico van bedrijven. Bedrijven met een laag risico besluiten eerder om eigenrisicodrager te worden dan bedrijven met een hoger risico. Voor zover dit om waargenomen kenmerken gaat, wordt hier in een multivariate analyse voor gecorrigeerd. Er kunnen echter ook niet-waargenomen kenmerken zijn. Een actief bedrijfsbeleid, gericht op beperking van verzuim en WAO-instroom, correleert met de WAOinstroom en ook met de keuze om eigenrisicodrager te worden. Voor dergelijke selectieeffecten is in de analyses gecorrigeerd, om de feitelijke invloed van het eigenrisicodragerschap op de WAO-instroom te kunnen vaststellen.

De resultaten in tabel 2 laten een WAOinstroomverlagend effect van het eigenrisicodragerschap zien. Naarmate het personeelsbestand veelal uit oudere mannen bestaat, wordt de kans op WAO-instroom groter. Bij vrouwen zien we een stijging tot ze 45 jaar worden. Daarna ontstaat er een daling, die mogelijk veroorzaakt wordt door een selectieeffect: alleen gezonde vrouwen blijven over in het arbeidsproces. Ten opzichte van de financiële sector (referentie) hebben alle sectoren behalve de horeca een kansverhogend effect op de WAO-instroom. Er is sprake van een dalende trend van de WAO-instroom, zo blijkt uit de geschatte constante term en de jaardummy's.
Het effect van eigenrisicodragen blijkt zich met name voor te doen bij werkgevers die in 2004 uitgetreden zijn uit het publieke bestel. Het effect van het historische WAOinstroompercentage is opvallend hoog. Dit effect verklaart indirect de selectiviteit in de keuze om eigenrisicodrager te worden.

Deze resultaten kunnen we gebruiken om de verwachte WAO-instroom te berekenen, een exercitie die niet gepubliceerd is in Zwinkels et al. (2006). We doen dit middels een simulatie van het verwachte WAO-instroompercentage voor 2004 per bedrijf. Daarna vermenigvuldigen we dit met het aantal werknemers van het bedrijf, zodat we de verwachte WAOinstroom per bedrijf krijgen, uitgedrukt in aantal werknemers.

Doordat de analyse betrekking heeft op bedrijven en niet op werknemers, komt het voorspelde aantal instromers in de WAO niet helemaal overeen met het gerealiseerde aantal in onze waarnemingsset. We modelleren immers het instroompercentage en niet de absolute instroom. Bovendien gebruiken we de effecten zoals geschat voor de periode 2001-2004 nu alleen voor 2004, waardoor ook een verschil tussen voorspelde WAOinstroom en gerealiseerde WAO-instroom kan ontstaan.

Wanneer we het relatieve effect gebruiken voor een doorrekening, waarbij dit effect proportioneel losgelaten wordt op de daadwerkelijke instroom in 2004, komen we tot het volgende resultaat. Als geen enkele werkgever eigenrisicodrager was geweest, dan waren er ongeveer 900 meer arbeidsongeschikten ingestroomd. Als de hele populatie eigenrisicodrager was geweest, dan zou de WAO-instroom met bijna 5.500 cliënten afnemen. Volledig eigenrisicodragen ten opzichte van volledig publiek verzekeren levert dus een totale besparing van ongeveer 6.400 werknemers die niet in de WAO instromen. Dit betekent op het totaal een beperking van de WAOinstroom met bijna 11 procent. 
Tabel 2 Schattingsresultaten WAO-instroom (random effects)

\begin{tabular}{|c|c|c|}
\hline & Parameter & $t$-waarde \\
\hline Constante & $-0,0714$ & $-42,8$ \\
\hline Eigenrisicodrager & $-0,0039$ & $-2,6$ \\
\hline \multicolumn{3}{|l|}{ Historische instroom } \\
\hline Als gelijk aan nul & $-0,0085$ & $-21,3$ \\
\hline Als groter dan nul & 0,1836 & 97,9 \\
\hline \multicolumn{3}{|c|}{$\begin{array}{l}\text { Leeftijd en geslacht } \\
\text { (referentie man 15-25) }\end{array}$} \\
\hline Man 25-35 jaar & 0,0219 & 5,3 \\
\hline Man 35-45 jaar & 0,0426 & 9,4 \\
\hline Man 45-55 jaar & 0,0530 & 10,2 \\
\hline Man 55-57,5 jaar & 0,0760 & 10,5 \\
\hline Man 57,5-65 jaar & 0,0791 & 10,5 \\
\hline Vrouw $15-25$ jaar & 0,0177 & 3,2 \\
\hline Vrouw 25-35 jaar & 0,0388 & 7,4 \\
\hline Vrouw 35-45 jaar & 0,0406 & 7,1 \\
\hline Vrouw 45-55 jaar & 0,0244 & 3,6 \\
\hline Vrouw 55-57,5 jaar & 0,0231 & 2,1 \\
\hline Vrouw 57,5-65 jaar & 0,0448 & 3,6 \\
\hline
\end{tabular}

\section{Sector}

(referentie financiële sector)

Primaire sector

Industriële sector

0,0273

0,0088

0,0033

Tertiaire dienstverlening,

vervoer en uitzendbranche

Horeca

0,0122

$-0,0018$

Zorg, cultuur en

(semi)overheid

0,0027

4,2

\section{Grootte van het bedrijf}

(referentie 10-20 werknemers)

20-50 werknemers

$>50$ werknemers

0,0102

0,0305

28,0

58,9

\section{Jaar}

(referentie 2001)

2002

2003

$-0,0029$

$-0,0121$

$-0,0133$

$-6,9$

2004

0,0504

Standaarddeviaties

Storingsterm (u)

0,0059

\section{Privatisering en toekomstig onderzoek}

De privatisering en decentralisatie hebben ook nog andere consequenties voor onderzoek naar de effectiviteit van re-integratie. Allereerst treedt er versnippering op. Private opdrachtgevers (met name verzekeraars) en gemeenten die onderzoek (laten) uitvoeren naar re-integratie, zullen dit alleen voor de voor hen relevante populatie doen. Het macrobeeld ontbreekt. Daarnaast zullen niet alle partijen hun onderzoeksresultaten altijd bekendmaken. Zoals eerder genoemd, kan dit te maken hebben met private informatie waarvan men liever niet heeft dat die ook voor concurrenten vrijelijk beschikbaar komt (zie ook Koning, 2005). Op de gemeentelijke re-integratiemarkt kunnen ook politieke processen een rol spelen om onderzoeken al dan niet openbaar te maken. Bovendien zijn voor onderzoek waarbij de effectiviteit statistisch betrouwbaar uitgesplitst kan worden naar cliëntkenmerken, aanbieder of proceskenmerken een flinke hoeveelheid waarnemingen van individuele cliënten nodig. Voor kleine gemeenten afzonderlijk kan dit een probleem vormen. Gegeven de betrekkelijk geringe aandacht voor onderzoek naar effectiviteit onder private verzekeraars (hoewel het totaalzicht daarop ontbreekt) is het de vraag of verzekeraars voldoende kennis bezitten om de financiële prikkel die zij hebben, om te zetten in effectief re-integratiebeleid. Het lijkt erop dat verzekeraars vrij terughoudend zijn met het aanbieden van trajecten (Koning \& Onderstal, 2004; Zwinkels et al., 2006). En zonder trajecten blijft er uiteraard weinig over om te evalueren.

Aan de opdrachtnemerkant doet zich daarnaast het probleem voor dat een (quasi-experimentele) controlegroep veelal ontbreekt, daar opdrachtnemers veelal alleen zicht hebben op de gevallen die zij zelf in traject nemen. Overigens kan tegen het bovenstaande ingebracht worden dat er in de vroegere situatie van voor de privatisering ook niet al te veel onderzoek gedaan werd dat voldeed aan de voorwaarden voor deugdelijke effectmeting.

\section{Kosten en baten van publieke en private re-integratie}

Tot nu toe is met name ingegaan op de gevolgen van privatisering voor de effectiviteit van re-integratie in termen van verhoging van de baanvindkans of het uitkeringsvolume. Niet minder belangrijk is de kosteneffectiviteit. De 
baten van re-integratie dienen afgezet te worden tegen de kosten. Bepaalde interventies kunnen effectiever zijn dan andere, maar ook zeer kostbaar. Ondanks hun grotere effectiviteit zijn de baten dan kleiner dan de kosten en kunnen beter de iets minder effectieve interventies ingezet worden. Uiteindelijk gaat het om een zo goed mogelijke prijs-kwaliteitverhouding voor het budget dat besteed wordt. Bij kosten-batenvraagstukken speelt ook de tijdshorizon een belangrijke rol. In hoeverre is re-integratie duurzaam of leidt reintegratie voornamelijk tot de creatie van draaideurcliënten, die zich na enkele maanden werk weer melden voor een uitkering? Inzicht in duurzaamheid is ook van belang om de kosteneffectiviteit op lange termijn van scholing goed te kunnen beoordelen. Dit instrument werkt veelal niet zoekduurverkortend (of zelfs zoekduurverlengend) maar mogelijk krijgt het individu bagage mee waar hij of zij zich gedurende veel langere tijd op de arbeidsmarkt kan redden dan bij andere instrumenten.

Voor de afweging tussen een publieke of private uitvoering van re-integratiedienstverlening speelt dus de vraag of privaat opdrachtgeverschap en opdrachtnemerschap zal prikkelen tot het inzetten van een meer kosteneffectieve re-integratie. Bij eenzelfde effectiviteit kan de private uitvoering mogelijk goedkoper zijn, aangezien er meer prikkels zijn om efficiënt te werken. De vraag blijft dan wel of lagere kosten ook doorgegeven worden aan premiebetalers of slechts leiden tot een hogere winst van private partijen. Er zijn ook hier weinig empirische studies bekend. Het CPB (2005) gaat in op literatuur over de verzekering van beroepsgebonden arbeidsongeschiktheid in Amerika. Interessant aan de Amerikaanse situatie is dat de organisatie rondom deze verzekering verschilt tussen de staten. Een van de verschillen is de keuze voor uitvoering via een volledig publieke regeling, een volledig private regeling of een combinatie van concurrerende private verzekeraars, een publiek fonds en/of eigenrisicodragers. De verschillen tussen de staten bieden de mogelijkheid om de effecten van publieke dan wel private uitvoering te analyseren. Uit empirische gegevens blijkt dat publieke fondsen lagere uitvoeringskosten hebben. Dit hangt voor een deel samen met schaalvoordelen bij een volledig publieke uitvoering en komt verder doordat publieke fondsen niet te maken hebben met voorzieningen voor reserves, belastingen, winstdeling en acquisitiekosten. Echter, substantiële verschillen in kosten tussen publieke en private uitvoering worden hier niet gevonden. In Zweden heeft de privatisering van de aan de Arbeidsvoorziening gekoppelde scholingsinstelling geleid tot kostenreductie (De Koning et al., 2005). Ook transactiekosten spelen een rol, dat zijn kosten die gemaakt worden om een contract tot stand te brengen en de kosten die daarna gemaakt worden om de overeenkomst te bewaken en zo nodig af te dwingen. Ook op dit punt is het onduidelijk welke gevolgen privatisering heeft gehad.

\section{Benodigde data}

Wat betekent het voorgaande nu voor de huidige en in de toekomst benodigde data voor effectiviteitsonderzoek? Allereerst is het lastig op basis van bestaande gegevens vergaande uitspraken te doen over effecten van privatisering. Gegeven de privatisering van opdrachtnemers zijn goede gegevens over de effectiviteit nodig om transparantie te bewerkstelligen in effectiviteitscores van aanbieders en om effectief aan te besteden, zodat de potentiële prikkels van marktwerking goed benut worden. Daarnaast zijn gegevens over de netto-effectiviteit van re-integratie onontbeerlijk om voor opdrachtgevers de beschikbare re-integratiemiddelen goed aan te wenden: wie krijgt welk traject wanneer?

Wat voor type gegevens zijn nodig voor goed effectiviteitsonderzoek? Allereerst zijn daarvoor betrouwbare gegevens nodig over de uitkeringsduur en over de reden van de uitstroom. Het eerste is in het algemeen van goede kwaliteit. Gegevens of de cliënt bij beëindiging van de uitkering uitgestroomd is naar betaalde arbeid of niet, zijn bij het UWV geen probleem maar binnen het gemeentelijke domein wel. Tot aan de introductie van de WWB waren administraties van gemeenten voornamelijk gericht op het correct verstrekken van uitkeringen. De uitstroomreden is niet altijd goed vastgelegd. 
Ten tweede zijn gegevens nodig over het traject. Begindata van trajecten zijn cruciaal en ook einddata zijn wenselijk om de effectiviteit zo goed mogelijk vast te stellen. Ook de inhoud (een goede typering) van het traject is belangrijk om de black box deels te kunnen openen: welke activiteiten leiden tot succes? Privatisering leidt ertoe dat aanbieders niet graag anderen een kijkje in hun keuken willen geven.

Ten derde zijn er gegevens over achtergrondkenmerken nodig om zo goed mogelijk te corrigeren voor selectie-effecten. Daarbij gaat het idealiter niet alleen om platte persoonskenmerken, zoals leeftijd, geslacht en opleiding maar ook om sociaal-psychologische kenmerken die een rol spelen bij het vinden van betaalde arbeid. Voor een concept als motivatie bestaan vanuit de psychologische wetenschap gevalideerde vragenlijsten. Er hoeft in dat geval minder vertrouwd te worden op de econometrische trukendoos van correctie voor selectie op basis van niet-waargenomen kenmerken. Op deze wijze kan ook onderzocht worden welke interventies bij welke groep cliënten meer of minder effectief zijn. Deze informatie kan vervolgens gebruikt worden bij de protocollering van interventies.

Ten vierde spelen ook proceskenmerken rond de aanbesteding een rol. Re-integratie is immers een zaak van opdrachtgever en opdrachtnemer. In Nederland zijn er nog onbenutte mogelijkheden voor onderzoek hiernaar. Dit kan licht werpen op de vraag wat belangrijk is bij re-integratie en hoe optimaal gebruikgemaakt kan worden van de marktwerking (zie ook Mallee et al., 2006).

Ten vijfde is niet alleen de effectiviteit maar ook de kosteneffectiviteit van belang. Dat vraagt naast financiële gegevens om longitudinale data waarbij individuen over een behoorlijke periode gevolgd worden. Alleen dan kan onderzocht worden hoe duurzaam effecten van re-integratie-inspanningen zijn.

\section{Conclusie}

De exacte gevolgen van privatisering zijn lastig kwantificeerbaar. Het is de vraag of pri- vatisering van de uitvoering van re-integratie geleid heeft tot een hogere netto-effectiviteit van re-integratiemiddelen. De inspanningen van de publieke arbeidsvoorziening waren destijds effectiever dan die van het gemiddelde re-integratiebedrijf op de private markt na introductie van marktwerking. Een simulatie van privatisering van het opdrachtgeverschap laat een reductie zien in WAOinstroom van 11 procent. De conclusie lijkt gerechtvaardigd dat privatisering geen al te grote gevolgen heeft gehad voor de effectiviteit, waarbij de verbetering van de effectiviteit door privatisering aan de opdrachtgeverskant waarschijnlijk grotere effecten heeft dan de privatisering aan de opdrachtnemerskant.

Privatisering kan theoretisch een gunstige uitwerking op de effectiviteit hebben, aangezien private partijen in het algemeen een grotere prikkel hebben dan publieke. Het kan zijn dat er na de privatisering enige tijd nodig is voordat gunstige effecten optreden. Essentieel daarbij is wel de vraag of private partijen in staat zijn de prikkel te effectueren.

$\mathrm{Nu}$ het waarschijnlijk is dat de privatisering niet meer teruggedraaid wordt, heeft het prioriteit om de potenties van marktwerking te benutten. Voor een deel is dit doorgaan op de weg van netto-effectiviteitsonderzoeken, teneinde via klantprofilering het beperkte re-integratiebudget zo effectief mogelijk in te zetten. Daarbij valt te hopen dat de centrale overheid zich niet volledig terugtrekt, maar zijn verantwoordelijkheid voor het stelsel serieus neemt en het UWV en gemeenten van de juiste prikkels voorziet. Daarnaast is ook een rol voor de landelijke beleidsmakers het transparant maken van de netto-effectiviteit in de vorm van een benchmark. In Australië heeft de invoering daarvan geleid tot een flinke sprong voorwaarts in de effectiviteit van re-integratie.

Systematisch onderzoek naar de netto-effectiviteit van re-integratie en goede data blijven noodzakelijk. Privatisering heeft versnippering van gegevens en van onderzoek tot gevolg. Ook kunnen concurrentieoverwegingen ertoe leiden dat gegevens niet uitgewisseld worden of onderzoek niet gepubli- 
ceerd wordt. Ook daar liggen aanknopingspunten voor overheidsingrijpen. Privatisering ontslaat de centrale overheid immers niet van de verplichting ervoor zorg te dragen dat publiek geld effectief besteed wordt.

\section{Noten}

1 Tevens geldt dat effectiviteit van aanbieders niet al te zeer mag fluctueren over de tijd. Effectiviteitscores over het verleden worden immers als basis gebruikt voor de verwachte effectiviteit in de toekomst.

\section{Literatuur}

Brouwer, P., W. Zwinkels \& J. van Genabeek (2006). Maatschappelijke kosten en baten van gesubsidieerde arbeid en sociale activering. Hoofddorp: TNO.

Centraal Planbureau (2005). Publieke of private uitvoering van arbeidsongeschiktheidsregelingen: casestudie verzekering van beroepsrisico's in de VS. Memorandum 117. Den Haag: CPB.

Graaf-Zijl, M. de, I. Groot \& P. Hop (2006a). De weg naar werk: onderzoek naar de doorstroom tussen WW, bijstand en werk, voor en na de SUWI-operatie. Den Haag: Raad voor Werk en Inkomen.

Graaf-Zijl, M. de, A. Heyma \& T. de Hoop (2006b). Van bijstand naar werk in Amsterdam: effectiviteit van reïntegratietrajecten voor bijstandsgerechtigden in de periode 2001-2004. Amsterdam: SEO.

Hekelaar, A., W. Zwinkels \& A. Braat (2006). De juiste klant op het juiste traject: een onderzoek naar de netto-effectiviteit van het Rotterdamse reïntegratiebeleid voor het ontwikkelen van klantprofielen. Rotterdam: SWA.

Heul, H. van der (2006). Vaststelling en evaluatie van de effectiviteit van reïntegratiemaatregelen voor WW cliënten. UWV Kennismemo 2006/11. Amsterdam.

Heul, H. van der, E.M. Berendsen, B.C.J.L. van der Eijken \& R.J.J. Vlek (2003). Op weg naar werk: een evaluatie van sluitende aanpak in de WW. Amsterdam: UWV.

Heyma, A. (2002). De effectiviteit van reïntegratieinstrumenten voor arbeidsgehandicapten. In: E.L. de Vos (red.). Daadwerkelijk effectief: prestatiemeting van reïntegratie en activering (pp. 97150). Heerhugowaard: PlantijnCasparie.
Heyma, A. (2005). Reïntegratie instrumenten voor WW-gerechtigden: behoefte, inzet en effecten. In E.L. de Vos \& J. van Genabeek (red.). Verraderlijk effectief: prestatiemeting van reïntegratie en activering, deel 2 (pp. 19-60). Amsterdam: PlantijnCasparie.

Heyma, A. \& W. Zwinkels (2004). Reïntegratie beter bij homogene groepen. Economisch Statistische Berichten, 89, 82-83.

Heyma, A., W. Zwinkels \& J. van Seters (2003). Doelgroepindeling aanbesteding reïntegratie: de relatie tussen persoonskenmerken, kosten en effectiviteit van reïntegratietrajecten. Den Haag: Raad voor Werk en Inkomen.

Kok, L., D. Hollanders \& J.P. Hop (2006). Kosten en baten van reïntegratie. Amsterdam: SEO.

Koning, J. de (2005). Actief arbeidsmarktbeleid: effectiever dan vaak wordt aangenomen. Tijdschrift voor Arbeidsvraagstukken, 21 (1), 1026.

Koning, J. de, A. Gelderblom, K. Zandvliet \& L. van den Boom (2005). Effectiviteit van Reïntegratie: de stand van zaken, literatuuronderzoek. Rotterdam: SEOR.

Koning, P. (2005). Heeft de evaluatie van reïntegratiebeleid nog toekomst? Tijdschrift voor Arbeidsvraagstukken, 21 (1), 27-37.

Koning, P. \& A. Deelen (2003). Prikkels voor UWV. CPB document no. 32. Den Haag.

Koning, P. \& S. Onderstal (2004). Reïntegratie als overheidstaak? Maandblad Reïntegratie, 4 (11), 35-37.

Mallee, L. J.W.M. Mevissen, J.E. Soethout \& H.A. Weening (2006). De re-integratiemarkt geijkt: evaluatie introductie marktwerking bij re-integratie van niet-werkenden. Amsterdam: Regioplan.

Ministerie van Financiën (2006). Regeling periodiek evaluatieonderzoek en beleidsinformatie 2006. Staatscourant 2006, nr. 83, p. 14. Den Haag.

Wevers, C.W.J., J. van Genabeek, B.M.F. Fermin \& E.L. de Vos (2006). Evaluatie SUWI 2006: perceel 2: werk boven uitkering. Hoofddorp: TNO.

Zwinkels, W. (2005). Prestaties van reïntegratiebedrijven vergeleken: Benchmarking van effectiviteit. In E.L. de Vos \& J. van Genabeek (red.). Verraderlijk effectief: prestatiemeting van reïntegratie en activering, deel 2 (pp. 61-93). Amsterdam: PlantijnCasparie.

Zwinkels, W., J. van Genabeek \& I. Groot (2004). Buitenlandse ervaringen met de aanbesteding van reïntegratiediensten. Den Haag: Raad voor Werk en Inkomen.

Zwinkels, W., P. Brouwer \& A. Braat (2006). Verzekerd van een effectieve prikkel: een verkennend onderzoek naar het effect van private uitvoering van de WGA. Hoofddorp: TNO. 